Walisongo: Jurnal Penelitian Sosial Keagamaan

Vol. 28 No. 1 (2020) pp. 29-48

DOI: $10.21580 /$ ws.28.1.5200

\title{
The Nationalism of Javanese Muslim Clerics: Study on Nationalism Discourse of Kitabs by Kiais of North Coast of Central Java in the XIX-XX Centuries
}

\author{
Muhamad Jaeni ${ }^{1 *}$ \\ ${ }^{1}$ Institute Agama Islam Negeri (IAIN) Pekalongan, Indonesia
}

\begin{abstract}
Treasures of the Javanese Muslim clerics (Kiais) thought on nationalism contained in their books have made a valuable contribution in maintaining Indonesia as a unitary state. Their papers discuss not only religious issues but also the values of nationalism. This study is aimed at examining the linguistic dimensions, the praxis-discourse, and the socio-cultural-political aspects of their books. It incorporates both critical discourse analysis and content analysis. From the profound analysis, the study concludes that, first, the texts concerning nationalism in a number of the Kiais' books can be seen through their linguistic dimension. These linguistic dimensions are partly found in the books written by Kiais from coastal areas. Second, at the level of praxis-discourse, those books are mostly written in Pegon script. The preservation of Arabic Pegon is meant not only to facilitate Javanese society in learning but also to indicate the Kiais' love of the local language, which is part of the national identity. Third, those books were mostly written during the struggle of the Indonesian people against the colonizers. While writing and teaching their religious texts, the pesantren Kiais instill values of the importance of loving and caring for the motherland.
\end{abstract}

Khazanah pemikiran para kiai tentang nasionalisme yang terkandung dalam buku-bukunya telah memberikan kontribusi yang sangat berharga dalam mempertahankan Indonesia sebagai negara kesatuan.

*Corresponding Author: Muhamad Jaeni (m.jaeni@iainpekalongan.ac.id), Jl. Kusuma Bangsa No. 9, Panjang Baru, Pekalongan, Indonesia 51141.

ISSN 0852-7172 (p) 2461-064X (e)

(C) 2020 by the Author, published by Walisongo: Jurnal Penelitian Sosial Keagamaan https://journal.walisongo.ac.id/index.php/walisongo 
Karya mereka tidak hanya membahas masalah agama tetapi juga nilai-nilai nasionalisme. Kajian ini bertujuan untuk mengkaji dimensi kebahasaan, praksis-wacana dan aspek sosial-budaya-politik buku mereka. Kajian ini menggabungkan analisis wacana kritis dan analisis konten. Dari analisis yang mendalam, studi ini menyimpulkan bahwa, pertama, teks-teks tentang nasionalisme di sejumlah kitab kiai dapat dilihat dari dimensi kebahasaannya. Dimensi kebahasaan ini sebagian ditemukan dalam buku-buku karangan para kiai dari daerah pesisir. Kedua, pada tataran praksis-wacana, buku-buku tersebut sebagian besar ditulis dalam aksara Pegon. Pelestarian Arab Pegon dimaksudkan tidak hanya untuk memudahkan masyarakat Jawa dalam belajar tetapi juga untuk menunjukkan kecintaan para kiai terhadap bahasa daerah yang merupakan bagian dari jati diri bangsa. Ketiga, buku-buku itu kebanyakan ditulis pada masa perjuangan bangsa Indonesia melawan penjajah. Saat menulis dan mengajarkan teks-teks agamanya, kiai pesantren menanamkan nilai-nilai pentingnya mencintai dan merawat tanah air.

Keywords: nationalism; kitab kuning; kiai; pesantren

\section{Introduction}

Today, with the ongoing transformation of a variety of understanding or ideology such as democracy in the freedom, movement of secular-religious comprehension and the opposite, fundamentalists, thus delivering Indonesian community to the disintegrating of the nation, one of which was triggered by national identity and the nationalism, which began to fade. It has been preserved by the clerics from century to century. The cleric of Islamic boarding school has kept the noble values that they have long defended and written in many academic works. The treasury of national thought of the clerics that is written in the ArabicJavanese books is realized to have a valued contribution of maintaining Indonesia as a unitary state. Because in fact, the books do not only discuss religious issues but also examine the values of nationalism that has been held as the community's grip in anticipating disunity. In other words, the clerics, as part of the nation element, have been able to play a role not only in the religious realm but also able to contribute significantly on the history of the nation foundation. Under the com- 
mand of Islamic clerics, Indonesian Muslims fought against the Dutch. They gave prominent colors to the struggle of the nation for its independence, primarily through the physical revolution (Farih, 2016, p. 254).

The national texts in the book written by clerics in Arabic-Javanese language, which is often called Pegon Arabic script. Discourse praxis that arises is how the clerics produce and transform the Arabic books into the local language. This process is aimed at making the content of the book easy to understand (build critical awareness) (Muhammad Sholeh, tt: 278). The existence of local language (Arabic-Javanese), is discursively aimed to fight against the Dutch colonial policy that accentuates the Latin language (Bizawi, 2016, p. 445). For example, Kiai Sholeh Darat who wrote the book of Tafseer of Faidh al-Rabmān with the pegon script. The use of the Arab Pegon script was a form of opposition to the Dutch political policy that at the time banned the translation of the Qur'an in local languages. This Dutch policy is supported by the fatwa of Sayyid Usman (1822-1913) in his book "Hukm al-Raḅmān fi al-Nahy 'an Tarjamah al-Qur'ān" (Gusmian, 2016, p. 362). The social discursive (Socio-cultural praxis) conducted by Kiai Sholeh Darat above seemed evident as a political reaction to the colonial policy. The way Kiai Sholeh Darat who opposes the policy of the invaders was also supported by other clerics of Central Java, such as Shaykh Abdul Hamid Kudus who allowed to interpret the Qur'an in a foreign language, as he wrote in his book "at-Tubfah al-Mardiyyah Fatwā fi Jawāz Tafsìr al-Qur'ān bi al-A'jamiyyah (al-Qandaly, n.d., p. $14)$.

Call for Javanese people to fight the colonialism of the invaders, was also written in the book of Kiai Muslih bin Abdurrahman Mranggen (alQandaly, n.d., p. 5). Likewise, the Kiai Asnawi Kudus, known for its firm in stemming the current of colonialism. His love of homeland has no doubt; this can be seen from his productivity in writing nationality verses. In addition, there are many more, the discourse of nationalism 
that is contained in the books of other scholars of the North coast of Central Java.

Departing from the explanation above, it is interesting to review the national thought of the clerics in their books how the device (dimension) of linguistic of the books is written as a social-religious educational medium that has a discourse praxis and socio-cultural that conditioned the clerics to give political influences in some of the writings. Some researches have been done, such as research of Ahmad Adaby Darban and Djoko Suryo (2014) entitled Rifa'yah: Gerakan Sosial Keagamaan di Pedesaan Jawa Tengah 1985-1982. Another study by Ali Maschan Moesa (2007) entitled Nasionalisme Kyai: Konstruksi Sosial Berbasis Agama. His second research tends to focus on the description of a movement. In contrast, this writing focuses on the element of the nationalism thought of the clerics by reviewing the field of discourse contained in the Arabic-Javanese, books of the clerics of North coast of Central Java in the century of IX-XX.

The approach used in this study is qualitative, with library research. The data collection methods used were observing, surveying, recording and spoken method. The method of reading is used to obtain data about all historical information, events, contextualization of texts through recordings, films, informant, etc. This is all related to the concept of nationalism of the cleric of the north coast of Central Java in the century of IX-XX. Another method is recording used to identify the text and reference books of Javanese translation of clerics in Central Java, especially those with explanations about the concept of nationalism or identifying information from other sources that support the explanation of the manuscripts studied. The next method is spoken method. In the social sciences, the method is known by the interview method (Mahsun, 2005, p. 250). This method is used to obtain data about the transformation process and the internalization of text and the discourse praxis of context that may influence and form the text dimensions, discourse praxis, and socio-cultural praxis that surrounded 
when the text was written. The data analysis in the study is content analysis.

\section{The Concept of Nationalism}

The word nationalism in Kamus Besar Bahasa Indonesia (KBBI) is defined as the awareness of membership in a nation that is potentially or in actually achieving, sustaining, and devoting identity, integrity, prosperity, and power of the nation (Pusat Pembinaan dan Pengembangan Bahasa, 2015, p. 954). As a national understanding, nationalism grew after the end of colonialism and imperialism in the Third World. If further detailed, the two views cause various forms of nationalism, namely nationality nationalism, ethnonationalism, romantic nationalism, cultural nationalism, state nationalism, and religious nationalism (Retno, 2007, p. 28).

Civic nationalism was popularized by Jean-Jacques Rousseau when he explained the concept of society in his famous theory on social contracts. This nationalism intends that the active involvement of the people has led a country to acquire its political truth. In other words, political truth rests on the truth of the will of the people and political representatives of the people. At the same time, ethnonationalism was popularized by Johann Gottfried von Herder, especially when he discussed the Volk. The intention of this nationalism is the political truth gained by the state grows. It is rooted in the cultural aspects of a society or community which membership is hereditary. According to Geertz, the movement of ethnonationalism can be seen in the separatism movement which is caused by the absence of justice and experienced by a certain ethnicity by other ethnicities (Geertz, 1992, p. 127). Regional jealousy can eventually evolve into a strong up to the point of gun rebellion.

Romantic nationalism believes that political clearance is derived from the source of a struggle of a particular tribe or race. The concept is the continuation of the ethnonationalism. The difference is the romantic nationalism emphasized on an old traditional tale that is redesigned in 
romance. Meanwhile, the cultural rationalism believes that political truths are derived from a common culture that is not unnatural such as skin colour, race and other. That is, in this understanding, the element of race is not regarded as a source of political truth.

An example is a Chinese nationalism in Taiwan. There, Taiwanese people refused to join China because of its communism but accepted China as a recognized cultural root. State nationalism is a combination of civic nationalism and ethnonationalism-for example, Nazism, nationalism in Belgium, and others. Lastly, religious nationalism believes that state truths are acquired through religious equations, for examples Iranian, Indian and Irish nationalism.

Kartodirdjo states that nationalism has several values consisting of unity, independence, equality, personality, and achievement or pride (Kartodirjo, 1999, p. 16). Moesa states that the values of nationalism consist of plurality, brotherhood, solidarity in diversity, line and love of Homeland (Moesa, 2007, p. 307). While Sri Uji Lestari, Ufi Saraswati and Abdul Muntholib, states that the values of nationalism include the love of homeland, sacrifice, the pride of diverse cultures, appreciate the merits of heroes and prioritize the public interest (Lestari, Saraswati, \& Muntholib, 2018, p. 206).

In the course of the nation's history, the cleric of Islamic boarding school as a figure of religious and society has a significant contribution in instilling the values of nationalism that they write in their works. The forms of nationalism displayed are also quite varied from the kind of national love based on citizenship, cultural similarities, and there are some forms of nationalism based on religious similarities. The emergence of nationalism texts in these books can be seen from how they place the linguistic devices in the text of the book and how the texts of the book are produced considering the situation and political conditions of the Indonesian nation at the time. 


\section{Form and Dimension of Text on the National thought in the Books of Central Java Muslim Clerics in the Century of XIX-XX}

Most of the texts containing the national values are spread in several books and only a small portion of the text that overall discusses the nationality written in one particular book. However, scattered text fragments have a linguistic device such as diction, paragraph or a cause and effect sentence, naming and involvement of the figure and also other linguistic devices that can show an emphasis on nationalism-inspired texts. For example, the national text in the Book of Syi'ir Ngudi Susilo by Kiai Bisri Mustofa has a dimension of text that suggests the importance of messages that readers must understand. In the book it is written:

"Lamun kita pada katekan sejane \# ora liwat sira kabeh pamimpine; Negaramu butuh menteri butub mufti \# butuh qadhi fatih setten lan bupati; Butuh dokter butub mister ingkang pinter \# ilmu agama kang nuntun laku bener; Butuh guru lan kiai kang linangkung \# melu ngatur negarane ora ketung ((Mustofa, n.d., p. 13).

Bisri Mustofa is careful enough to choose the word (diction), especially in emphasizing the importance of mutual responsibility in advancing the nation and state. The term "kita" in sentences; "Lamun kita pada katekan sejane, ora liwat sira kabeh pamimpine" was deliberately chosen to demonstrate that advancing the nation is a joint responsibility. This sentence also has a causal element. Some status/ position such as ministers, regents, doctors and others are intentionally mentioned clearly so that the readers understand that these officers play an essential role in a country. Another text of Kiai Bisri can be found in the book" Durar al-Bayan fi Tarjamah Syu'ab al-Iman". The core of this national text shows the importance of citizens being loyal to the government. The text is written:

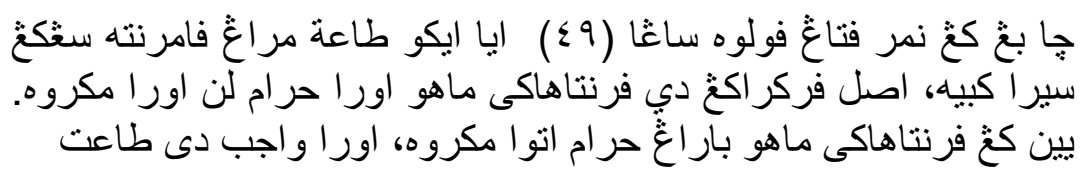

(Mustofa, 1952, p. 2) 
The word "tha'at" which has become a loanword in Bahasa Indonesia, is deliberately used for the importance of following the government. Similarly, the diction of word "harām", "wājib", "makrüh", all have semantic elements that are quite emotive, so the text is impressed to have a message that is important be understood by the reader. Another national text is about the importance of loving Indonesian traditions and culture. This teaching is also reflected in the Book of Syi'ir Ngudi Susilo:

"Akeh bocah pinter nanging ora bagus \# budi pekertine sabab da kemagus; Ring wong tuwo gak gregani gak ngajeni \# sjak pinter dewek langka kang madani; Jare iu coronipun sa'puniko \# ora ngono dudu intelek merdeka; Ngagem blangkon sorban sarung dadi gujeng \# Coro ora kebangsaan ingkang majeng; Sawang iku pangeran Diponogoro \# Imam Bonjol Tengku Umat kang kuncoro; Kabeh pada bela bongso lan negoro \# podo ngagem distar pantes yen perwiro". (Mustofa, n.d.)

The text above has the process of inserting information related to the phenomenon of young children who have the ability but do not have moral. This information insertion effort is aimed at readers to understand that there has been moral degradation among the nation's children. The word "ora" for "ora ngono dudu intelek merdeka" or "ora kebangsaan ingkang majeng" is a linguistic strategy of word structure to rephrase the next sentence. It is related to the typical Indonesian clothing culture that is considered "Kampungan". The author also inserts the information in the form of a character engagement as a previous sentence antithesis. The mention of the name of a hero such as Pangeran Diponegoro, Imam Bonjol and Teuku Umar, they are the ones who also have the hero soul and love the traditions and culture of their homeland.

In addition to dressing style, the use of Javanese language is also the identity of national culture that is held by the cleric of Islamic boarding school. This can be proved by the abundance of translations and even the writing of the Pegon-written books. Pegon script is a Javanese language register written in Arabic script. Many terms refer to the 
variety of languages (words) of Java used in the process of writing and translating the book. Kiai Shaleh Darat named it "Al-Lugah al-Jāwiyyah al-Mrikiyah". Kiai Bisri named it "Tembung Daerah Jawi”. While Kiai Muslih calls it with the term "Tembung Dairah Jawi Mriki”.

Politically, a variety of pegon script as writing media and translation of the books of Islamic boarding school is a form of expression and political attitude of the Javanese coastal scholars towards the Dutch colonial policy at the time. One of the policies is that there is a prohibition for the headman to use Pegon as a medium in interpreting the Qur'an. Dutch policy above raised protests from the clerics. One of them was from Sheikh Abdul Hamid Kudus, who wrote the book on the possibility to interpret al-Qur'ān with the local language (Javanese):

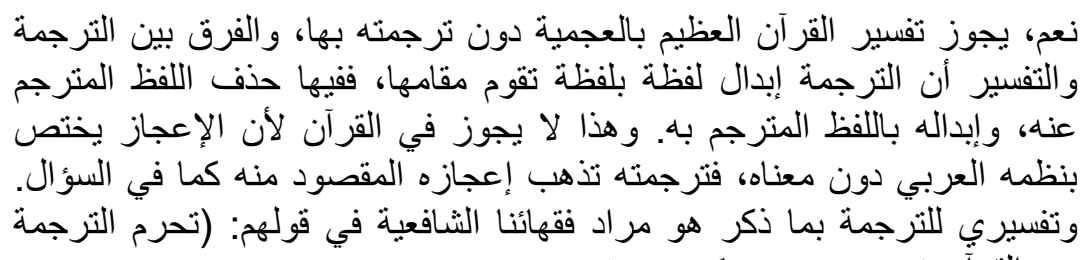

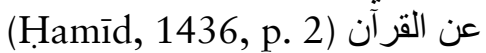

Regardless of the opinion of the cleric about which is allowed between translating and interpreting, it is clear that the Javanese language as the media used by the cleric is an essential cultural entity and is correctly noticed by Javanese people. This position is proof that clerics love the culture of our own.

Kiai Ahmad Rifa'i Kalisalak also writes other national texts. The text contains the importance of casting out the Dutch that has been colonialized and oppressed the people of Indonesia for a long time. With the fight and repel the colonizers, it is expected that Indonesia soon became an independent country. The text reads

"Tanbihun! Wong kafir melebu negara Islam \# Dadi raja negara Jawi wus dawa; Iku strune mu'min khas lan awam \# Iku fardlu 'ain diperangi kafaham; Ngelawan ing raja kafir kinaweruhan \# Rati Islam maring raja kafir anutan; Bupati, Demang ngawula asib-asihan \# Maring raja kafir anut parintahan." (Rifa'i, 1965, pp. 10-11). 
The linguistic element in this text is very powerful. Especially the diction of "Wong kafir" addressed to the Dutch. The word kafir is included in the religious terminology so that every mu'min feel moved to be together to fight the invaders. The sentence used also contains a causal element. Each mu'min is compulsory to fight against the disbelievers as they enter into the territory of the Islamic country, and it has been very long. Here it is seen that the author of the book intentionally develops religious nationalism. The figure engagement (such as regents and village headman) in the text is also bright enough. In this regard, the authors would like to point out to the readers that the officials did the conspiracy with the colonial authorities.

The efforts of the resistance and the expulsion of invaders are essential for the nation's independence. Independence is the goal and ideals of Indonesian people; there is no exception for clerics of Islamic boarding school. Therefore, no wonder, when the independence arrived, the clerics welcomed it with a sense of joy. One of them perceives this joy. He is kiai Raden Asnawi who then wrote in the form of Arabic poem:

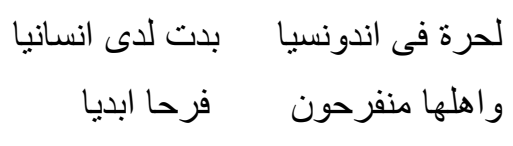

(Mas'ud, 2013, p. 95)

The text of the poem above has a causal element. In this case, the author wants to show that citizens will only get happiness when the nation becomes an independent country. Kiai Abdul Mu'ti also writes the importance of independence. The text is only a translation of the book of the Arabic text. Kiai Abdul Mu'thi mentions four kinds of independence. First, individual independence; Second, Freedom of assembly; Third, economic independence; and fourth; Political independence. Redaction of the explanation text in the book is as follows: 


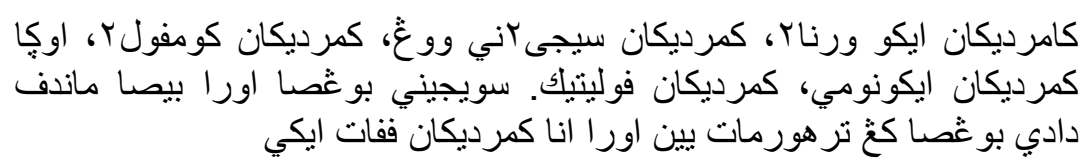

(Mu'thi, n.d., p. 183)

The text above is an informative narrative of the concept of independence. The sentence text also has a logical relationship that has a linkage between the terms and the desired outcome. The word "Ora bisa mandep" with the word "Yen ora Ono" are closely related words. A nation will not be a respectable nation if there are no four types of independence that have been already described by the author. There are still many national texts contained in the books by clerics of Islamic boarding school. The texts have the linguistic dimensions that give the text messages to be understood by the readers.

\section{Discourse Praxis in the National Text in the Books of Central Java Scholars in the Century of XIX-XX}

As what has been already explained in the beginning that most of the national texts are spread in some books of clerics written in the local language (Javanese). The variety of Javanese language used has its characteristic. Some experts call it the language of Jawa Kitabi, some of which call it the Islamic language as well as Javanese of pesantren. This language of Jawa Kitabi can be said to be unique, where the Javanese language is written in Pegon Arabic script. Meanwhile, the text structure uses fusha Arabic.

Jawa Kitabi language as Javanese language with character in literacy aspect and linguistic dialect is a variety of religious Javanese language because the lexical reference refers to the coastal dialect of Javanese. In contrast, the grammatical refers to Arabic grammar Standard or Fusha Arabic. The appearance of Jawa Kitabi language as developed Javanese grammar that is adopted fully from fusha Arabic necessitate the linguistic syncretization with the feature of inculturation between Arabic which serves as the language of the source and Javanese as the target 
language due to religious Islamization processes. The developed Javanese language, of course, necessitate the appearance of Pegon script as a proof of the existence of Islamic Javanese script and also require the grammar urgency of Islamic Javanese called Jawa Kitabi language (Ali, 2012, p. 6).

The maintaining of Arabic Pegon in producing national texts in addition to facilitating the public as well as a form of love and pride of the clerics to the local language that is as part of the identity of the nation of Indonesia. The use of the Pegon script also has a political dimension, in which a variety of script is a protest media against Dutch policies that prohibit translating and interpreting the Qur'an in the local language. Similarly, the policy to ban the headman from using Pegon script as a medium of correspondence among them. It is said that the Pegon script is also used to deceive the Dutch so that they (Dutch colonizers) do not understand Arabic writing. Therefore, the kiai Rifa'i himself named the books of Javanese translation with Tarajumah (Amin, 1994, p. 53). The Dutch only knew that Tarajumah was a translation of the Arabic books by the Middle East scholars.

The use of Pegon Arabic script is a cultural and ideological movement conducted by the Kiai Rifa'i and also the community of Rifa'iyah (the follower of Rifa'i), in which the pegon Arabic is a characteristic of local loyalty of the Javanese community (Rif'iyah) at that time and became a cultural binder among them. The pegon Arabic written in Tarajumah is a "resistance" language to confront the colonial. Moreover, the community formed through Islamic teaching with Tarajumah's book has a strong social bond that worries the colonial government on one side and traditional bureaucrats on the other hand. The fanaticism of relationships among fellow members often transcends the boundaries of blood relations so that the people of Rifa'yah that one is the brother of the other (Djamil, 2001).

Kiai Ahmad Rifa'i (1786-1870 AD) is one of the productive clerics in writing books, especially books in Javanese with very high literature 
values. His books are the adaptation of books in Arabic of previous scholars with a basis from al-Qur'an and Hadith. The books were then named Tarajumah. The books of Tarajumah are primarily written with the pegon script in the form of poem. The books in the form of poetry are those who make the community interested in reading and learning.

National texts are also widely written by Kiai Bisri Mustofa (19151977 AD.). He is one of the most prominent coastal scholars who is rich with his monumental books. From the data collected, there are about 54 books written by the cleric from Rembang both in the form of syair and natsr. Even other sources mention the number of works of Kiai Bisri is more. Kiai Muhammad Shaleh bin Umar (1820-1903 AD.) is another coastal scholar who is also productive in writing and translating books into Javanese. The nationalism attitude of Kiai Shaleh is undoubted because he was born and grown in a family that loves the homeland. His father was the Kiai Umar, a respected scholar in the northern coast of Java. He was a Javanese warfighter (1825-1830 AD.), even he was the right-hand man of Prince of Diponegoro. Kiai Umar and friends, colleagues, and students struggled to defend the honor of the homeland from the Dutch colonies.

The cleric of other coastal who is also a figure of scholars and fighters is the Kiai Raden Asnawi Kudus (1861-1959 AD). He wrote many of the nationality poems as described in the beginning. There are many of the coastal clerics in Central Java producing national texts in Javanese language narrative. They are for example Kiai Ahmad Abdul Hamid Kendal (1915-1998 AD), Kiai Muslih bin Abdurrahman Demak (1908-1981 A.D), Kiai Ahmad Muthahar Demak (1926-2005 A.D), Kiai Yahya Arief Kudus (1923-1997 AD.), Kiai Akhmad Syakowi Amin Pekalongan (1920-), Kiai Subki Masyhadi Pekalongan (1933-2011 AD).

Strong bonds of brotherhood and nationality also arise because there is a network of communication among the clerics. The communication network is not only done in daily activities but also academic activities. The form of scholarly communication is usually written in the 
comment's sheets of the books. If there is a cleric writes or translates the text, then often the cleric will ask for correction as well as comments, notes, or preface from other clerics. Thus, the clerics, the authors of the book continued to build communication on the discourse praxis. This action can be seen from many notes/comments in the written translation books.

The comment of the cleric in a book is usually termed "taqriz", which means "review". Lexically, the word "taqriz" itself means "alMadh" which means praise. Therefore, most of the Taqriz contents are usually praise and expressions of happiness for the composed of written or translated books, like the example in the book of Kiai Syakhowi Amin Pekalongan. It is written Taqāriz al-Ulamā al-Kirām wa alMashāyikh al-'Alām li al-Risālah Jauhar al-Adh'iyyah. Taqrīz was first written in Javanese-Pegon by Sheikh Ahmad Abdul Hamid al-Qandaly. The second Taqriz is also written in Javanese-Pegon by Kiai Zainal Abidin Dimyati Buaran Pekalongan, and the third Taqriz is written in the same language by Sheikh Abdurrahīm al-Karanji al-Pekalongan.

Likewise, in the book Nail al-Anfāl fi Tarjamah Tubfah al-Aţāal by Kiai Ahmad Muthahar Mranggen Demak. At the end of the book, there is a taqrīz sheet of Kiai Muslih bin Abdurrahmān. In the book of Risālah al-Nisā': Risālah Huqūq al-Zaujain" In the works of Kiai Ahmad Abdul Hamid Kendal, there were also two sheets of taqriz from the Syekh Muhammad Hambali al-Samarany and Syekh Abdul Jalil Hamid alQasimi (al-Qandaly, n.d., p. 47). And there are still many other books commented by other coastal clerics. The taqridh of some of the books was done in addition to the normal academic tradition undertaken by clerics. It is as the form of a sign that they always want to show the importance of developing togetherness and establishing brotherhood of countrymen.

The national texts in the religious scriptures written by clerics are studied in some of the Islamic boarding school. This condition causes the teachings contained in the books is continually transformed to the 
students. Even as time goes on, the texts in the books have also been spread and read by the community widely. Islamic boarding school is also one of the independent boards where the general public can also follow the learning process. Hence, the social teachings in religious books are not only accessible by students but also the general public.

\section{Sociocultural Praxis Contained in the text About the National Thought in the Books of Central Java Scholars in the Century of XIX- XX}

The national texts that are written by clerics in the books of Islamic boarding school are not separated from the situation and social conditions that occurred at the time. The situation and condition of socio-cultural that occurred in the XIX century is a condition that is not so beneficial for people of Indonesia. Politically, the Indonesian nation was under the power of colonizers. The domination of the colonizers to Indonesia, not only on its natural resources but also in the process of the public's boycott with the lack of access of indigenous people to get an education.

The above conditions triggered the scholar figures to appear in the fight for the independence of the Republic of Indonesia. This awareness comes mainly from several clerics who are studying in Haramain. They felt of being called, and then they came home. They are committed to the transformation of religious teachings to the community through the process of learning in the Islamic boarding school and writing and translating books (Gusmian, 2016, p. 224). Nevertheless, the books that were written massively do not only contain religious knowledge but also discuss the values and teachings of the importance of loving the homeland.

Syi'irs of protest found in Tarajumah is evidence that Kiai Rifa'i wanted to invite the Javanese people to be brave against all forms of oppression committed by the kafir (Dutch colonizers). Likewise, the religious book written by Kiai Bisri contains the values of the loving 
homeland. Even Kiai Bisri himself did not only struggle for public awareness but also get himself directly into the battlefield. So, it is not surprising if Kiai Bisri is familiar with the history of the foundation of this nation. He wrote a particular book on the history of Indonesia Beaksara Pegon, the book of Târikh al-Auliyā'.

The other coastal cleric who also went home to the homeland and fought through the writing of the religious book is Kiai Shaleh Darat. The Book of "Faidh al-Rahmān" written in Arabic-Javanese is regarded as a form of resistance against the Dutch policy that prohibits the translation of the Qur'an in the local language (Javanese). The Dutch itself considers that the pegon Arabic script as Javanese script and language which is not standard so that the variety of language is categorized as a local community language. However, the policy of the prohibition is not located on the use of Javanese language, but more to the Dutch fear of the Javanese people can understand the content of the Qur'an.

Socially and politically, the dialect of Javanese language that later became a special language of the Islamic boarding school is a linguistic history development that has the content of discriminatory treatment. This condition is partly due to the process of contact with other languages, such as true Arabic (Fusha) and also of Palace language that is considered standard and is a variety of high-class languages. It is a Dutch strategy to keep people away from the Javanese of Islamic boarding school.

The historical fact supports the explanation above that shows the negative attitude towards Jawa Kitabi language as the academic language of Islamic boarding school. Genealogies of Jawa Kitabi (Islamisch Javaansche) was adopted from the coastal Javanese language which is a representation of the ngoko Javanese in the new Javanese language hierarchy. The existence and significance of ngoko Javanese in the discourse of the power of the Palace-is declared as a variety of modern Javanese in the context of Javanese language hierarchy of the 
lowest, corrupted and less civilized Javanese language, so ngoko Javanese of the coastal domain is regarded as Barbaarsch Javaansche, a Javanese language spoken collectively by the "barbarians" Javanese who do not know the "palace manner" because they live and interact outside the palace walls (Ali, 2012, pp. 8-9).

The use of Pegon script is also considered to diverge from the tradition of writing the Carakan script, which is culturally widely used in the palace environment. While the Javanese people in the north coast of Central Java see the opposite, the language variety of Palace Javanese is a representation of communication language that is loaded with "freeze", and the labelling is loaded with "political hegemony of linguistic". The continuing contact with the language of pegon and the dialect of ngoko of the coast was used as a science language in the Islamization movement in the coastal areas of Java. There is much more negative embedding to the Jawa Kitabi language used by clerics, students and other community of Islamic boarding school.

\section{Conclusion}

The national texts contained in several books of clerics can be seen through the linguistic devices existing in it. The linguistic devices such as the selection of the word (diction) used the paragraph or cause and effect sentences, the naming and involvement of figures and other linguistic analyses used in the books of the Central Javanese scholars. These linguistic dimensions are partly included in the books written by the cleric of Coastland such as the book of Tarajumah, the book of Tärikh al-Auliyā, the book of Syi'ir Ngudi Susilo, the book of Durar al-Bayān fi Tarjamah Syu'ab al-Imān, the book of Iddah al-Balighin fī Tarjamah "Iddah al-Nashi'in, the book of al-Tuhfah al-Mardiyyah Fatwā fi Jawāz Tafsìr al-Qur'än bi al-A'jamiyyah, the book of Muqaddimah al-Qanūn al-Asasi li Jam'iyah Nahdah al-Ulamā', the book of al-Nașā'ih alDiniyah min Diwān Maj'mū' li al-Shi'ir li al-Haji Ibn Hadhar Mudhakir, kitab Wașaya al-Aba' li al-Abnā', and many other books. 
At the level of discourse praxis, national texts contained in the books of coastal clerics is mostly written in Pegon Arabic script. Pegon script is part of the Javanese language structure that is used in Islamic boarding school which is often called Jawa Kitabi language. Jawa Kitabi language structure is a variety of Javanese language written in Arabic script. While the sentence structure usually uses the structure of fusha Arabic. The maintaining of Arab Pegon to produce national texts in addition to facilitate the Javanese community, it is also as a form of love and pride of the clerics to local language that is a part of the nation's identity. Even Arabic-Javanese is a variation of language in the political dimension, where the language variety is used as a protest media to the Dutch policy, which contents are the prohibition to translate and interpret the Qur'an and religious texts with Pegon script. Sociolinguistically, a variety of Jawa Kitabi language is a lingua Franca of Islamic boarding school community especially the clerics in writing national texts on their books such as Kiai Ahmad Rifa'i, Kiai Bisri Mustofa, Kiai Sholeh Darat, Kiai Raden Asnawi, Kiai Ibn Hadjar Mudzakir and several other coastal clerics.

The emergence of the national texts in the books of coastal clerics is not separated from the situation and social conditions that occurred at the time. Most of the books were written during the movement of Indonesian people against the invaders. Indonesian people do realize that there are dominance and exploitation of the colonizers to the country of Indonesia, not only on natural resources but also in the process of the community's boycott with the absence of access to education for indigenous people. This condition caused the clerics to feel being called to participate in the awareness efforts for the community and encourage them to fight the form of occupation and strive to get independence. The clerics of Islamic boarding school keep trying to write and teach religious books, which have the values and teachings on the importance of loving and caring for the homeland.[w] 
The NATIONAlism of JAVANESE MUSLim CleRics ....

\section{References}

Ali, M. (2012). Urgenitas Bahasa Jawa Kitabi sebagai Identity Marker Kitab-Kitab Turats al-'Araby di Pesantren Jawa Timur. In Artikel Bunga Rampai Buku. Surabaya: Airlangga University Press.

Amin, A. S. (1994). Pemikiran Kiai Haji Abmad Rifa'i tentang Rukun Islam Satu. Jakarta: Jama'ah Masjid Baiturrahman.

Bizawi, Z. M. (2016). Materpiece Islam Nusantara: Sanad dan Jejaring Ulama-Santri (1983-1945). Tanggerang: Pustaka Compass.

Darban, A. A., \& Suryo, D. (2014). Rifa'iyah, Gerakan Sosial Keagamaan di Pedesaan Jawa Tengah Tabun 1850-1982. Universitas Gadjah Mada, Yogyakarta.

Djamil, A. (2001). Perlawanan Kyai Desa: Pemikiran dan Gerakan Islam KH. Abmad Rifa'i Kalisalak. Yogyakarta: LKiS.

Farih, A. (2016). Nahdlatul Ulama (NU) dan Konstribusinya dalam Memperjuangkan dan Mempertahankan Negara Kesatuan Republik Indonesia (NKRI). Walisongo: Jurnal Penelitian Sosial Keagamaan, 24(2), 251-284. https://doi.org/10.21580/ws.24.2. 969

Geertz, C. (1992). Tafsir Kebudayaan. (F. B. Hardiman, Trans.). Yogyakarta: Kanisius.

Gusmian, I. (2016). Tafsir al-Qur'an Bahasa Jawa: Peneguhan Identitas, Ideologi, dan Politik Perlawanan. Suhuf: Jurnal Pengkajian alQur'an dan Budaya, 9(1), 141-168. https://doi.org/10.22548 /shf.v9i1.116

Hamīd, 'Abdul. (1436). Al-Tuḅfah al-Mardiyyah Fatwā fi Jawāz Tafsìr al-Qur'ān bi al- A'jamiyyah.

Kartodirjo, S. (1999). Multidimensi Pembangunan Bangsa Etos Nasionalisme dan Negara Kesatuan. Yogyakarta: Kanisius.

Lestari, S. U., Saraswati, U., \& Muntholib, A. (2018). Penanaman NilaiNilai Nasionalisme dalam Pembelajaran Sejarah Lokal Perjuangan Rakyat Sukorejo Kelas XI di SMA Negeri 1 Sukorejo. Indonesian Journal of History Education, 6(2), 205-15.

Mahsun, M. (2005). Metode Penelitian Bahasa: Tahapan Strategi, Metode, dan Tekniknya. Jakarta: Rajawali Press.

Mas'ud, A. (2013). Kyai tanpa Pesantren (Potret Kyai Kudus). Yogyakarta: Gama Media. 
Moesa, A. M. (2007). Nasionalisme Kiai: Konstruksi Sosial Berbasis Agama. Yogyakarta: LKiS.

Mu'thi, 'Abdul. (n.d.). 'Iddah al-Balighin fī Tarjamah 'Iḍdah alNashi'in. Pekalongan.

Mustofa, B. (n.d.). Syi'ir Ngudi Susilo. Kudus: Menara Kudus.

Mustofa, B. (1952). Durār al-Bayān fi Tarjamah Syu'ab al-Imān. Kudus: Menara Kudus.

Pusat Pembinaan dan Pengembangan Bahasa. (2015). Kamus Besar Bahasa Indonesia. Jakarta: Gramedia.

al-Qandaly, A. 'Abdul Hamīd. (n.d.). Risālah al-Nisā': Risālah Huqūq al-Zawjayn. Semarang: Al-Munawwar.

al-Qandaly, M. bin A. (n.d.). Al-Nūr al-Burhān. Semarang: Karya Toha Putra.

Retno, L. (2007). Pendidikan Kewarganegaraan. Jakarta: Gelora Aksara Pratama.

Rifa'i, A. (1965). Abyan al-Hawā'iz. 